\title{
Assessing Electronic Waste Disposal Practices as a Function of Reverse Logistics: Evidence from Kumasi Metropolis, Ghana
}

\author{
Emmanuel Kwabena Anin \\ Department of Procurement and Supply Chain Management \\ Faculty of Business and Management Studies. Kumasi Polytechnic, Ghana \\ Johnson Djan-Yeboah \\ School of Business \\ Kwame Nkrumah University of Science and Technology Kumasi, Ghana \\ Stephen Okyere \\ Department of Procurement and Supply Chain Management \\ Faculty of Business and Management Studies. Kumasi Polytechnic, Ghana
}

\begin{abstract}
The use of electronic products has grown substantially over the years. Modernity is constantly changing people's life style and reflects in changes in tastes and preferences for electronic products and services. This contributes to generation of tonnes of electronic wastes which, due to their toxic content, pose serious challenges to human, wild and aquatic. This study assesses electronic waste disposal system in the Kumasi metropolis of Ghana. This study was crosssectional in nature and adopted qualitative approach. The study relied on primary data using interview and observation instruments. Electronic products repairers, scrap dealers and officials of Environmental Protection Agency (EPA) in Kumasi constituted the target population. Qualitative data collected was analysed through deduction in inferences. Findings from the study revealed that there seem to be no clear cut strategy of e-waste disposal being practised within the metropolis. It was also identified from the study that resource constraints faced by EPA for monitoring and education on e-waste disposal, ineffective collaboration between EPA and the law enforcement agencies and the other stakeholders for effective enforcement of the policy were the major challenges. We recommended the need to educate the public on the toxicity of e-waste and its harmful effects on human, wild and aquatic life. There should be clear and specific electronic waste policies in place to govern and regulate the disposal of electronic waste in Ghana.

Keywords: Electronic Waste, Waste Management, Waste Disposal, Reverse Logistics, Kumasi Metropolis, Ghana
\end{abstract}

\section{INTRODUCTION}

Electronic products are among the commonest gadgets that facilitate both human and business activities. Businesses and human activities daily depend on the usage of these products creating demand for its production. However, when the products have reached their end of life, disposing them becomes an issue because of their non-degradability and the toxic contents which if not handled well can pose danger to the environment. Electronic waste (e-watse) is arguably the fastest growing waste stream. It is causing damaging impacts to our environment due to the toxicity of the components (Musson et al, 2000; Jun-Hui \& Hang, 2009; Nnorom, Osibanjo, 2008; Hadi, Barford, McKay (2013 ). 
The growing pattern of e-waste is most certain to increase at an alarming rate due to people's desire to have variety of electrical and electronic gadgets. Thus availability of high-tech electronic equipment and desire for people to use these modern gadgets is a contributing factor to the surge in e-waste (Noon et al, 2011).

Electronic waste (e-waste) refers to the electrical and electronic products which have reached their advanced stage of life and are due for disposal or reuse by extracting the usable portion from it for another purposes. These products include equipment such as computers, cell phones, ipads, television sets, refrigerators, air conditioners, washing machines, toasters and any other electronic material one can think of (BAN, 2005; Guptha, Sheka, 2009; Asente-Duah, Saccomanno, Shortreed, 1992; Noon et al., 2011). Ghana, like other developing countries, is a victim to e-waste due to the importation of old electronic materials from advanced economies. This problem has been compounded following the desire and misconceptions that used electronic products from Europe and other countries are better than the new ones. Again, there is also perception that some importers import inferior electronic products under the pretext of affordability despite the fact that low quality goods do not last. The end result is rampant and abandoned e-waste in the environment.

Disposal of e-waste is concerned with getting rid of, and management of unserviceable, obsolete or surplus stock of electronic products in an environmentally safe manner (Antrekowitsch, et al, 2006, cited Nnoron, Osibanjo, 2008). Most of the components of electronic products are hazardous and could be harmful to both human and wildlife (Jun-Hui, Hang, 2009; Musson et al. 2000, and Musson et al., 2006,cited Noon et al., 2011).

Prior studies have established the challenges e-wastes pose to the environment and human life (Lincoln et al. 2007, Musson et al. 2000, and Noon et al., 2011), yet it seems that the attention given to the problem is not enough. The hazardous and toxic nature of most e-wastes requires effective and environmentally safe disposal strategies (Musson et al. 2000; Leung, Cai, Wong, 2004; Sinha,2004).

Again, it appears that disposal of obsolete electronic products in Kumasi, mostly, are left in the hands of local repairers of electronic products and scrap dealers to salvage the components needed. In order to deal with these life threatening phenomena, there is the need to explore into the practices to appreciate the situation on the ground and to come out with findings that will inform policy decision regarding e-waste management and disposal. Therein lays the justification of this study to assess electronic waste disposal strategies as a function of reverse logistics in the Kumasi metropolis.

The rest of the paper is organised as follows. First, we review previous literature related to electronic wastes management in section 2. We then describe our methodological approach in section 3. In section 4, we present the analysis and discuss our findings. Finally, we draw conclusion, put forth our recommendations and limitations in section 5.

\section{Electronic and Electrical Equipment}

\section{LITERATURE REVIEW}

Electronic waste (E-waste) is the term used to describe Electrical and Electronic Equipment (EEE) that have been discarded. E-waste comes from electronic and electrical products such as computers, television, microwaves, mobile phones, printers and so on (Guptha, Shekar, 2009). Leung et al., (2004) defines e-waste as electrical and electronic products (e-products) that have outlived their usefulness and are due for recycle or disposal. The e-products may include information and telecommunication technology equipment such as cell phones, computers, printers and any of such products. Robinson (2009) refers e-waste as an informal term for e- 
products that are getting to the end of their useful life. Thus discarded computers, printers, television set and radio set are typical examples of e-waste. What makes e-wastes an issue of concern is the toxic and hazardous contents of most, if not all, these products and their adverse effect on the environment (Hadi, Barford, McKay, 2013; Guptha, Shekar, 2009).

Guptha and Shekar, (2009) argue that the increasing rates of e-waste generation that engulf most countries are fuelled by the rapid obsolescence of EEE. The increasing growth in technology coupled with the shortening products life cycle have aggravated the situation.

In Africa, tonnes of used EEE are shipped into the continent, posing disposal challenges. The Brigden et al.,(2005). say that The e-wastes produced in various sectors mainly end up with the informal recyclers where recycling is done in a very crude and hazardous manner causing danger to, not only the environment but also to the people involved in the recycling activity. The report added that environmental hazards in city are likely to increase if electronic waste is not tackled quickly.

\section{Sources of E-Waste}

Tonnes of e-waste generated in the developing countries may take its origin from two distinct sources. These include local generation and importations of used electronic materials, also referred to as second hand products from the developed economies. Local generation stems from the use of newly acquired e-products. Most of the e-wastes are also generated from used e-products imported from European communities such as Great Britain, Belgium, Netherlands, and Denmark among others. Piles of used electronic materials are shipped from these countries to the developing countries under the pretext of what is claimed to be "bridging the digital divide". In most cases these scraped computers, mobile phones, fridges to mention a few, are dysfunctional or obsolete as they had already reached their end of designed service life, posing challenges to e-waste management (Adu-Gyamera et al., 2013). For example Basel Action Network (BAN) (2005) observed that about 25-27\% of the imported second-hand computers to Nigeria are unusable. This perhaps account for the huge tonnes of e-waste generated in Ghana making management of e-waste even more challenging and difficult to handle (Anna et al. 2008; Taye and Kanda, 2011; Furter, 2004).

\section{Managing E-waste Disposal}

Consumption of electronic products has been intensified over the years, perhaps due mainly to the desire of recent generation to consume high tech electronic products. The life span for electronic products is very difficult to determine. It may be due to how the holder of the product will handle it. As e-products gets into the hands of consumers, most of them develop faults due to the usage rate and obsolescence (Antrekowitsch, et al. 2006, cited Nnoron, Osibanjo, 2008). Most of these e-wastes find their way in the hands of scrap dealers locally known in Ghana as "condemn". Unlike the developed countries like US where 3.2 million tonnes of e-waste were sent to landfills in 1997, according to Antrekowitsch, et al. (2006) cited Nnoron, Osibanjo, 2(008), in the developing countries, these wastes are disposed off indiscriminately without any regard to the negative environmental implications. Some of the components of e-wastes contain toxic chemicals which have the potential to pollute the soil and the ground water (Hadi, Barford, McKay, 2013).

Different approaches to e-waste management have variously been used across the globe, especially in the developed economies. These range from recycling to landfill disposal. Countries like Switzerland use framework based on a model referred to as the Extended Producer Responsibility (EPR). The EPR model is a system that places the responsibility of recycling and disposal of electronic products which have reached their End of Life (EoL) in the 
hands of producers (Hadi, Barford, McKay, 2013). Widmer et al (2005), also cited Taye and Kanda (2011) note that European Commission requires manufacturers and importers of electronic products in the European Union to take back their products from consumers and properly disposed them off using environmentally safe approach of disposal. Taye and Kanda (2011) opine that, this system and policy of e-waste disposal should be adopted here in Africa and in Ghana in particular if e-wastes are to be well managed in order to save our polluting environment. Taye and Kanda continue to argue that most countries are yet to develop an organised collection, segregation, recycling, disposal and monitoring system of e-waste generated for the safety of the environment.

According to Furter (2004), the commonest approach by which e-waste is managed in the developing economies includes low-end treatment methods. These include backyard recycling, burning, and dumping (sometimes into water bodies). The crude approach of disposing off ewaste is life threatening. Hazardous materials such as lead, mercury batteries, liquid crystal displays, and cartridges from photocopying machines among others can seriously affect the environments. If Cathode ray tubes (CRTs) is crushed and burnt, it emits toxic products into the atmosphere (Hadi, Barford, McKay, 2013). According to Guptha and Shekar, (2009). the chemical substances from mobile phone batteries is enough to pollute $600 \mathrm{~m} 3$ of water

Best practice approach to disposal of e-waste as a function of logistics in the developed economies takes the form of:
Re-use: where the used product has not reached EoL and transferred to other areas for re-use by auction or donation.
Repair: where the use and malfunctioned e-products are refurbished for reused.
Remanufacture: where the malfunctioned e-product are taken back through reverse logistics to the producer to remanufacture the products.
Re-cycling: where the used products are collected to make new products.

Disposal: where the used product is finally sent to landfill or destroyed using scientific approach (Taye and Kanda, 2011; Gupta, Shekar, 2009; Musson et al., 2006; Singh and Walia, 2011; cited Hadi, Barford, McKay, 2013; Advanced Tropical Environment (ATE), 2012; Sinha, 2004).

\section{Challenges of Disposal of E-Waste}

Disposing of certain elements can be costly due to the material composition, legislations and high disposal lead times. E-waste cannot be processed until the products that have reached their end of life are collected from consumers through reverse logistics (Guptha, Sheka, 2009; Noon, Lee, Cooper, 2011).

Luo et al. (2011), state various options of collection such as collection from permanent drop-off site, retail stores, regular curb side - pick up (collection at home or office) as needed, scheduled pick-up, and special collection events. The major challenges have been the separation of e-waste from other wastes from point of origin or generation and the logistics cost of collection. Another challenge facing e-waste disposal management has to do with how to streamline and control e-waste disposal in the developing countries like Africa in the face of seemingly non-existence of specific policy on e-waste disposal (Guptha, Sheka, 2009; World Bank, 2007)).

Perhaps the biggest challenge is the issue of resource availability for educating public on safe disposal of e-waste. It appears people are not well informed about the dangers e-waste could cause to human health. For instance, at Agbogloshie in Accra, it is common to see young scrap 
dealers using their bare hand dismantling electronic waste to harvest the metallic components and burning the residue (Adu-Gyamera et al., 2013).

\section{Reverse Logistics Activities}

The Council of Logistics Management (1998), cited gives definition of logistics as "The process of planning, implementing, and controlling the efficient, cost effective flow of raw materials, inprocess inventory, finished goods and related information from the point of origin to the point of consumption for the purpose of conforming to customer requirements".

Reverse logistics is quite different from the traditional logistics, or forward logistics. Reverse Logistics as business process is increasingly receiving growing attention due to concern for environmental sustainability (Rogers \& Tibben-Lembke, 2002). Some countries across Europe have enacted laws on taking-back used electronic devices for effective disposal management (Kokkinaki et al., 2002). Again reverse logistics activities may have been driven by commercial interest. That is most companies adopt reverse logistics as a strategy to contributing to green environment, build positive image and gain competitive advantage.

Reverse logistics primarily, is concerned with the process of recycling products (Krumwiede \& Sheu, 2002), According to Kroon and Vrijens (1995), "Reverse Logistics refers to the logistics management skills and activities involved in reducing, managing and disposing of hazardous or non-hazardous waste from packaging and products". Stock (1998), also refers to Reverse Logistics as "the role of logistics in product returns, source reduction, recycling, material substitution, reuse of materials, waste disposal, and refurbishing, repair and remanufacturing".

From the definitions above, it could be seen that reverse logistics may involve three categories of activities. These include direct reuse, product recovery, and waste management activities. Thus reverse logistics function could offer effective means of managing and disposing off ewaste. These definitions stress on waste management and disposal for environmental sustainability.

Carter \& Ellram, (1998) and Giunti \& Andel, (1995) argue that Reverse logistics has important environmental dimensions since it can reclaim value by means of remanufacturing, repair, reconfiguration, recycling and safe disposal of waste. It is also argued that reverse logistics should be seen as an opportunity to build competitiveness by investing more resources into it in order to enhance operational performance and commercial benefits (Stock et al., 2002; Minahan, 1998l; Richey et al., 2005). According to Rogers and Tibben-Lembke (1998), firms are motivated to invest into reverse logistics by five (5) factors. These include: competitive advantage, Clean Channel, Legal compliance, recapture value recover assets as well as safe disposal. These factors constitute the basic reverse logistic activities and can offer good opportunity and approach for managing e-wastes.

\section{METHODOLOGY}

This study is cross-sectional in nature and adopted qualitative approach using primary data. Repairers of electronic products, scrap dealers and officials of Environmental Protection Agency (EPA) constituted the target population of the study. A quota of five (5) respondents from five (5) refurbishing/repairing shops each were purposively and conveniently selected from Kwadaso, Santasi, Suame, Aboabo and Tafo sub-Metros, whilst ten (10) e-scrap dealers were selected using snowballing sampling approach. In addition, five (5) officials from EPA were involved in the study. Representatives from EPA were used as key informants. These were also selected purposively, making for a sample size of 40 . These categories of 
respondents were selected in view of their involvement in or knowledge on disposal of e-waste within the metropolis and so could give relevant information.

Primary data was collected using interview and observation instruments. A set of semistructured interview were administered to solicit views from repairers, scrap dealers and the officials of EPA. Open ended questions were used in the interviews. This allowed the researchers to explore and probe for in-depth information. The responses were recorded for analysi.

Field observation was also conducted to afford the researchers the first hand information on disposal of e-waste within the metropolis. The researchers visited various repairing shops and e-waste dumping sites within the study setting and observed things themselves to get more insights on the real situation on e-waste disposal within the metropolis. In the observation process, relevant information on disposal of e-waste within the metropolis was recorded. The qualitative data collected was analysed through deduction and inferences and content analysis. This was supported using pictures taken from various sites of e-wastes disposal.

\section{ANALYSIS, RESULTS AND DISCUSSIONS \\ Disposal of E-Waste Practices (EPA's Perspective)}

The study sought to assess how e-wastes are disposed off in the metropolis. It was revealed from the interview session that, EPA's strategy is to collaborate with entities or individuals that intend disposing off e-wastes by playing supervisory role in the disposal process. The disposal process involves dismantling the product to extract useful components such as: copper, aluminium, and other metals, while the waste components are sent to the landfill at Dompoase, Kumasi for dumping and burying.

According to the EPA officials, the useful components are usually sent to the e-waste dealers and repairers for re-use. Thus the disposal of e-wastes, supposedly, should follow the process of Collecting, dismantling, extraction and separation of useful components from the waste for re-use and dumping or burying the residual wastes at the landfill.

It emerged that this process is followed only when an entity notifies EPA on its intention to dispose off its e-wastes. From the interview, it seemed that few entities link up with EPA when disposing off their e-wastes. This is partly due to the fact that most entities send the wastes to the individual scrap dealers while others dispose them by auctioning and transferring to other entities and so do not handle the residual waste of e-products themselves.

This strategy, i.e. EPA's collaboration with institutions and individuals for e-waste disposal appeared ineffective due to the lack of strict enforcement of waste disposal policy in the metropolis and so people dispose off their generated e-waste their own way. This accounts for the indiscriminate disposal of e-wastes in the metropolis without recourse to the precarious consequences on the environment.

\section{Disposal of E-Waste Practices (Scrap Dealers' Perspective)}

The study also sought to assess waste disposal situation from the scrap dealers' perspective. Ewaste dealers in the Kumasi Metropolis include repairers of e-products, scrap dealers and collectors or distributors of e-waste. These are major stakeholders in terms of disposal of ewastes. Results from the interview session with the scrap dealers indicated that the collectors engage in house-to-house collection of e-waste from consumers and repair shops within the metropolis. The collected e-scraps are distributed to the various dealers scattered across the metropolis, in areas such as Suame, Aboabo among others for amount ranging from GH\$10.00 
to $\mathrm{GH} \$ 15.00$ per unit of e-product. Hence their primary motive is the economic benefits rather than the environmental sustainability.

The scrap dealers dismantle the e-waste products manually to extract the useful components, which include mother-boards, copper wires among others, and sell to other organisations in Tema and Accra. The residual e-wastes are disposed off by either burning or dumping. According to the dealers, a kilo of mother-board was sold for a minimum of GH\$50.00, one of the most expensive components of e-waste.

It also came out from the interview session, and the observations made that sometimes, the extraction of the useful components are crudely made by setting the e-wastes ablaze in the open weather (see figure 4.5). When asked why they choose to burn the waste in the open weather under no expert supervision, one of the dealers said:

"We burn the waste because it is easy and fast approach of extracting useful components. Also, when we leave the residual e-waste to the city waste authority, they feel reluctant to take them to the landfill because of their bulky nature. They also demand money from us before collecting the residual e-wastes so we decide to burn them during the night".

As revealed from our observation (figures 4.1-4.4), it is obvious that the approach used by these scrap dealers to extract various useful components from the e-scraps appeared crude and risky. In fact the burning of e-scrap is even more serious as several toxic fumes are released into the atmosphere in the process. This is supported by Wu et al (2008), when they found from their study in China that a single cell phone can bring a considerable toxicity to the environment.

Sometimes, the residual e-wastes are dumped into water channels, thus blocking drains and causing flooding. The implications of this to residents in the area, including the scrap dealers themselves could be dire (Sinha, 2004).

This process of e-waste disposal is similar to that carried out in some other jurisdictions and confirms the findings of Adu-Gyamera et al., (2013) from a study conducted at Agbogloshie in Accra. Their findings revealed that young scrap dealers engaged in e-waste business with their bare hands to dismantle e-wastes to harvest the metallic components like copper and consequently exposed to health hazards. The unwanted parts especially, the plastic waste components are usually set ablaze like bonfire.

It is also reported by Roman and Puckett (2002) that, e-wastes are dumped or disposed off into river bodies after the scrap dealers have extracted what they wanted, blocking water ways and drains. Again this finding is supported by Sinha, (2004) and Furter (2004), when they state that, burning and dumping of e-wastes as a disposal strategy is detrimental to the environment since most e-wastes contain several kinds of harmful substances capable of contaminating the environment especially if they are burnt.

The disposal of e-waste as revealed by the study clearly falls short of best practice as posit by (Musson et al, 2000; Jun-Hui \& Hang, 2009; Nnorom, Osibanjo, 2008; Hadi, Barford, McKay (2013). Best practice on e-waste management requires that disposal be made at landfill under strict supervision of experts (Musson et al, 2000; Jun-Hui \& Hang, 2009; Nnorom, Osibanjo, 2008; Hadi, Barford, McKay (2013 ).Figures 4.1-4.5 show pictures of how e-wastes are disposed off in various places within the metropolis. Pictures were taken with the permission of the scrap dealers for ethical reason. 


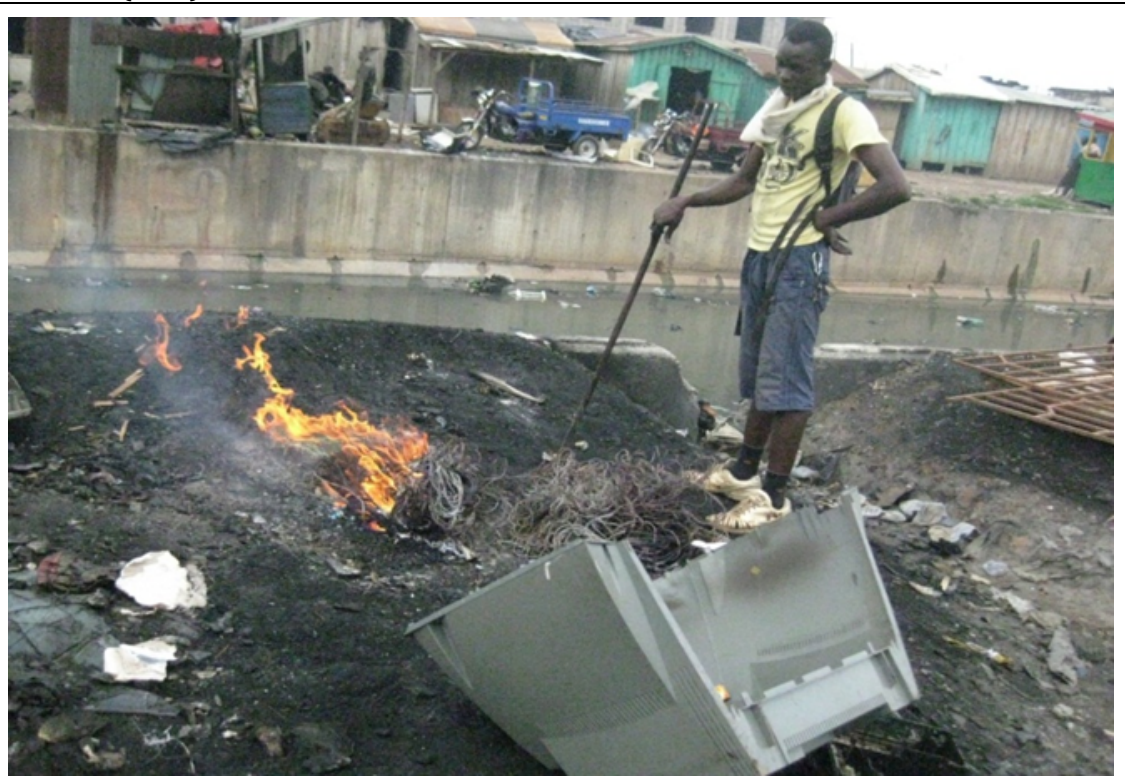

Figure 4.1: A scrap dealer burning electronic waste to extract useful components. (Source: Author's field work, 2014).

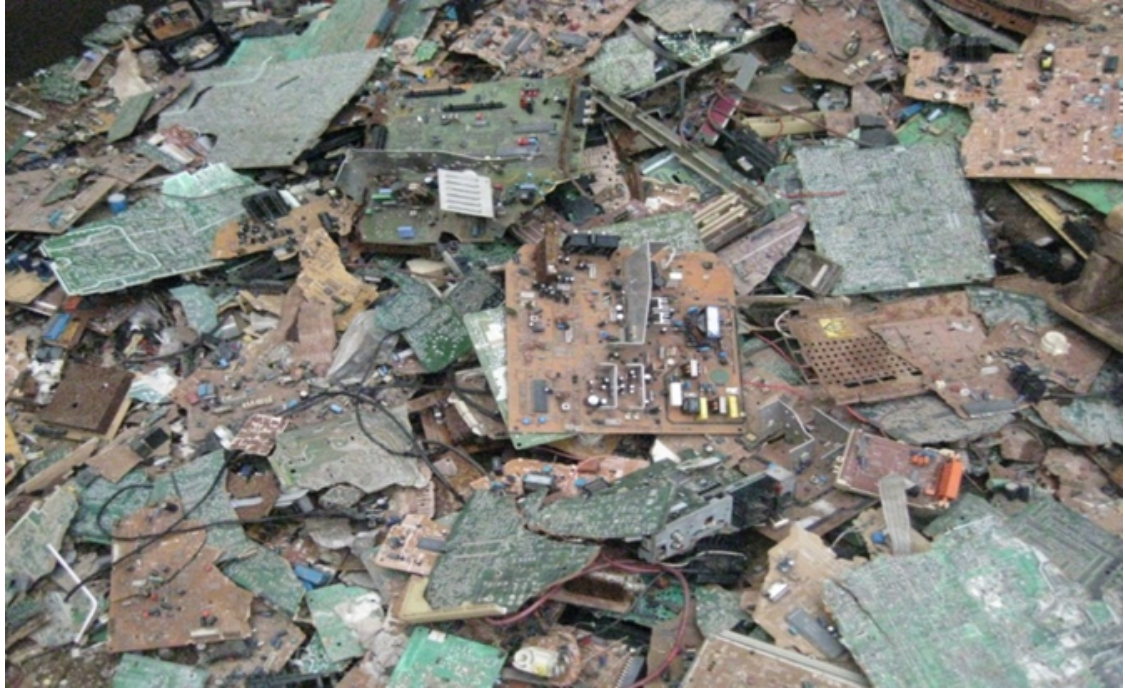

Figure 4.2: Openly disposed electronic wastes at Santasi, Kumasi

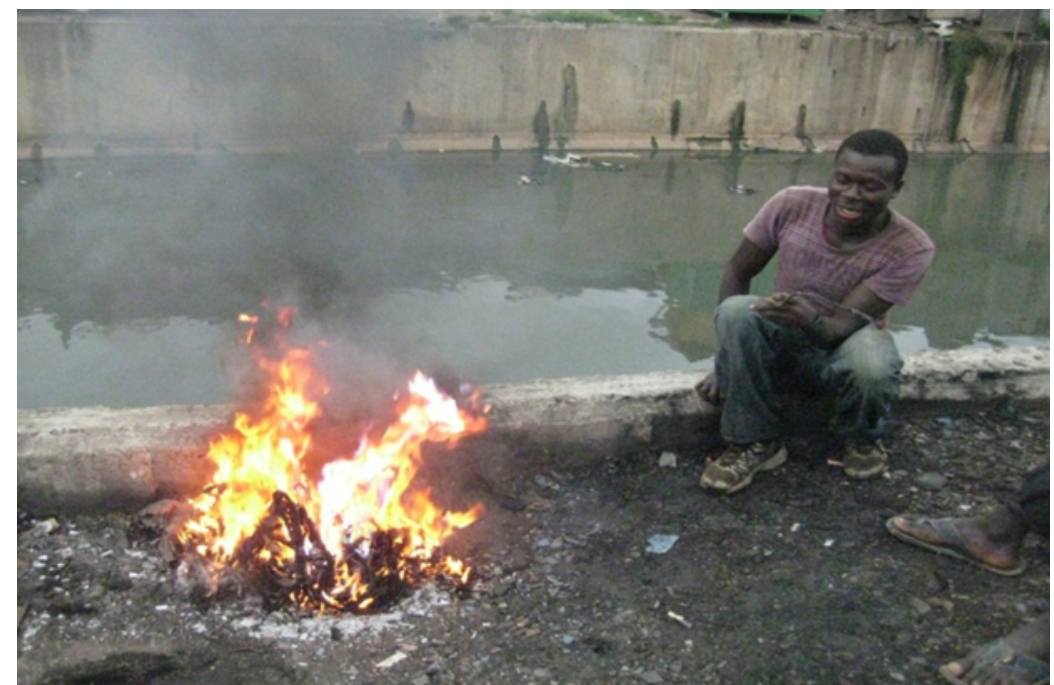

Figure 4.3: Burning of Electronic Waste. (Source: Author's field work, 2014).

Again our observations revealed that the amount of e-waste collected by these dealers was surprisingly huge. When the pile of waste gets to a level, (see figure 4.5 and 4.6), dealers themselves use their own approach to dispose off the wastes, usually by dumping and burning. 
Figure 4.4 shows a disposed electronic waste in water way at one of the places visited in Kumasi.

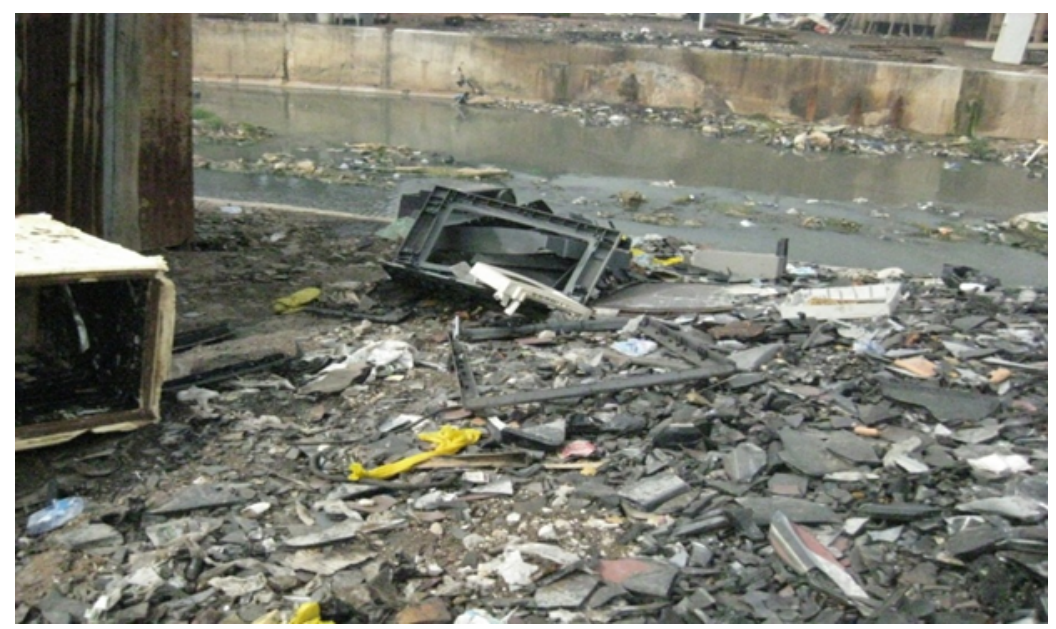

Figure 4.4: Disposed electronic waste in water way at Aboabo, Kumasi

(Source: Author's field work, 2014).

Figure 4.4 confirms the assertion that, Mehra (2004), inappropriate disposal of e-wastes can be harmful and dangerous to environment.

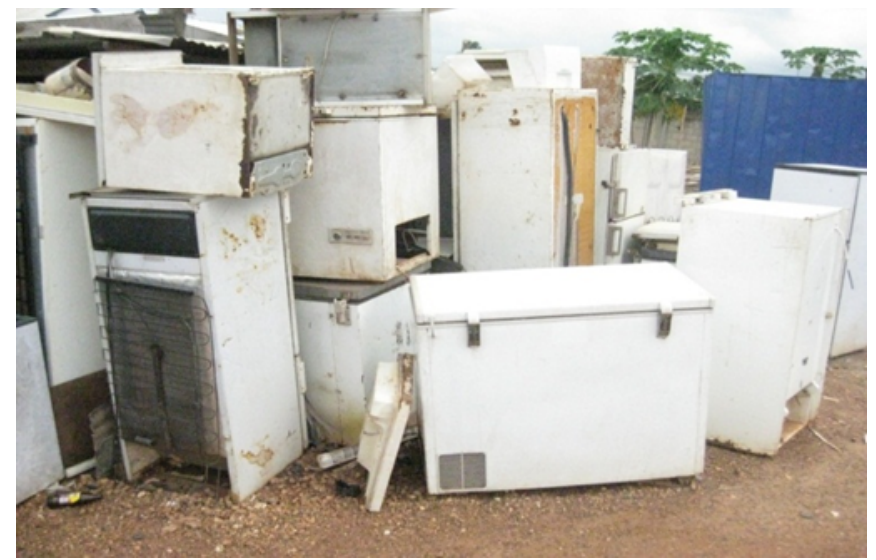

Figure 4.5: A pile of abandoned electronic e-wastes at Kwadaso, Kumasi

(Source: Author's field work, 2014).

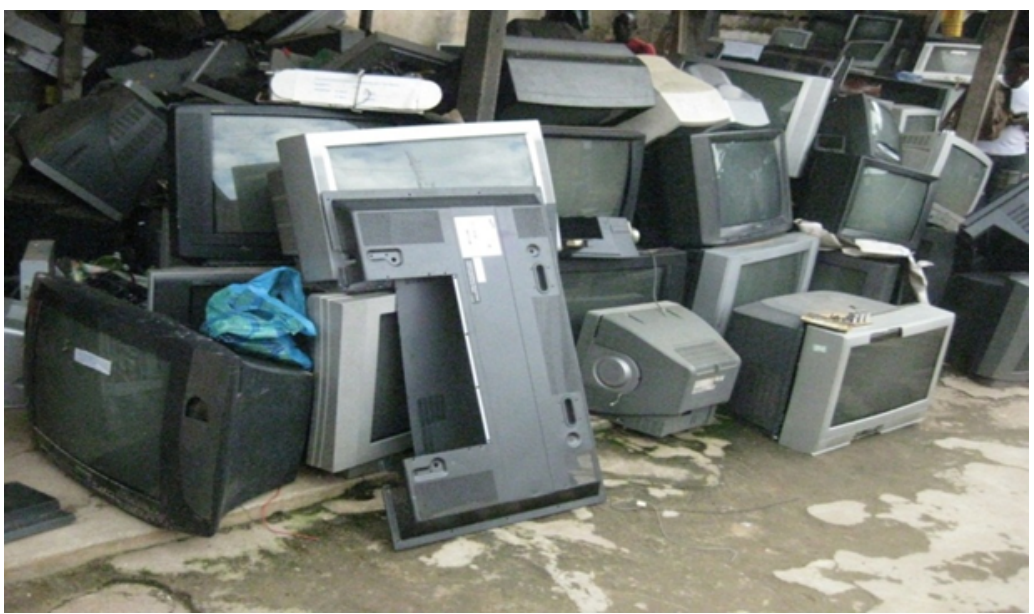

Figure 4.6: A pile of abandoned electronic waste at Tafo, Kumasi (Source: Author's field work, 2014). 
Thus, it was clear from the interview session and the observation made that there seem to be no clear cut approach on how we dispose off e-wastes within the metropolis. As such, players in the sub-sector adopt their own approach in managing e-waste without recourse to any policy. This arises from the fact that no law enforcement agency on e-waste management questions this seemingly crude approach to e-waste management used by the scrap dealers.

The interview also assessed the extent of awareness on the environmental implications of their approach to e-waste disposal. It was realized that majority (80\%) of the dealers contacted, to a very extent, were aware of the environmental consequences of their activities on e-waste. One of the dealers stated that "the smoke from the burning cause discomfort to the residents of that area. People complained about how they were suffering each time we burnt the waste. So these days we do most of the burning at night instead of day time."

From the statement made, it is clear that somehow, the dealers are aware of the environmental consequences yet, because their commercial interest overrides environmental consciousness, they keep on using the same approach. Perhaps, because the activities are not restricted by any law, they see nothing wrong about their actions. Their commercial interest simply overrides environmental consciousness.

\section{Challenges Facing E-Waste Disposal in the Metropolis}

The study also sought to explore into the challenges inherent in the e-waste management system within the metropolis. It was revealed from the interview with the EPA officials that, one major challenge is the seemingly non-existence of specific policy on e-waste disposal although there is policy on waste disposal in general. As a result, dealers in e-scrap are less informed about appropriate and safe means of disposing off e-waste.

Another challenge has to do with attitudinal change of the public. According to the EPA, in spite of their educational campaign on environmental sustainability through responsible disposal of waste, people still choose to dump waste, including e-waste indiscriminately within the city.

Another challenge identified from the responses given by EPA was the ineffective collaboration between EPA and the law enforcement agencies. According to the EPA, there seem to be disconnect among these stakeholders of e-waste management in terms of enforcing regulations on waste disposal. As such it has been particularly challenging for the EPA to deal with recalcitrant scrap dealers and individuals who indiscriminately dump wastes (including ewaste) within the metropolis.

Resource constraint was yet another challenge limiting the efforts of EPA in dealing with ewaste in terms of monitoring and educational campaign on waste management. As a result of resource constraint, the EPA and other law enforcement agencies were not aware of some of the activities of the scrap dealers within the metropolis because of ineffective monitoing. This seemed to have given the scrap dealers undue advantage to adopt any means possible to dispose off the e-wastes they handle. In fact, from the scrap dealers' perspective, it was confirmed that they are not aware of existence of any policy governing waste disposal in general, much less on e-wastes within the city and therefore find their approach to e-waste disposal normal.

\section{CONCLUSION}

The main objective of the study is to assess electronic waste disposal strategies as a function of reverse logistics in the Kumasi metropolis. The study revealed that there seem to be no clear cut strategy by which e-wastes are disposed off within the metropolis. As such, players in the 
sub-sector adopt their own approach (mostly crude) in managing and disposing off e-waste without recourse to any law and impact on the environment.

The outcome from the interview session as well as the observations made during the study indicates that e-waste disposal in the Kumasi Metropolis falls short of best practice and raises environmental and health concerns (Musson et al, 2000; Jun-Hui \& Hang, 2009; Nnorom, Osibanjo, 2008; Hadi, Barford, McKay, 2013). Burning and dumping of e-waste in areas other than landfill at Dompoase- Kumasi, is common in the metropolis. Indeed, visits to various refuse dumping sites in Kumasi revealed the extent to which e-waste is treated as ordinary wastes. The approach of e-waste disposal obviously has long-term adverse implications to human, wild and aquatic life (Mehra, 2004; Sinha, 2004).

It was also identified from the study that resource constraints faced by EPA for monitoring and education on e-waste disposal, ineffective collaboration between EPA and the law enforcement agencies and the other stakeholders to enforce waste policy were the major challenges.

Nevertheless, the situation also has economic implication as the e-waste processes and disposal chain serves as sources of income to some stakeholders within the sub-sector of reverse logistics. It is this income generation opportunities that incentivize and motivate hundreds of individuals to develop the "waste value chain". The implication of this finding makes it imperative to, as a nation, review and development policy framework that will seek to regulate waste disposal process for the e-waste sub-sector. This will not only improve reverse logistics activities as a function of waste disposal in the metropolis but also, and more importantly, address the environmental and health related challenges whilst creating opportunity for economic, social and environmental sustainability.

\section{RECOMMENDATIONS}

Based on the findings and the conclusions drawn from the study, we recommend that the EPA and other agencies should educate the public on the toxicity of e-waste and its effect on human, wild and aquatic life. Again in order not to dispose off waste indiscriminately, Parliament of Ghana, as a matter of importance, should enact policy that will regulate e-waste disposal. Government and other organizations should consider recycling as an approach for managing ewaste whilst creating opportunity for employments.

There should also be continuous training for scrap dealers to empower them on management and safe disposal of e-waste. Finally, Government may consider placing a ban on the importation of used electronic products into Ghana given the danger e-waste products pose to the environment and the general public. Mostly these products do not only generate tonnage of waste in the country but also are high energy consuming. Such move will reduce the amount of e-waste generated annually in the country, thus saving resources and protecting the environment.

\section{LIMITATIONS AND SUGGESTIONS FOR FURTHER RESEARCH}

The study has some inherent limitations. The findings are based on limited sample size and cross-sectional data. Therefore we suggest that future research should consider longitudinal research design with larger sample size to make a more generalized conclusion.

It will equally serve research interest if future study should look at the economic dimension in terms of the contributions of e-waste supply chain to economic growth. 


\section{References}

Adu-Gyamerah, E. (2013). Public Accounts Committee Sits Today [online], available at: www.modern Ghana.com/news/.../public-accounts-committee-sits-today.htm...[accessed on 15 May, 2014].

Advanced Tropical Environment (ATE) (2012). Identification of the Magnitude of ThElectrical and Electronic (EWaste) Situation In South Africa: A Strategic Approach to International Chemicals Management (Saicm) E-Waste as an Emerging Policy Issue, The Africa Institute for Environmentally Sound Management of Hazardous and Other Wastes, and The Department of Environmental Affairs.

Anna O.W. and Leung (2008). Heavy Metals Concentrations of Surface Dust From E-Waste Recycling and its Human Health Implications in Southeast China. Environmental Science and Technology. 42, (7)2674-80.

Asente-Duah, D.K., Saccomanno, F.F. and Shortreed, J.H., (1992). The waste trade: can it be controlled? ES \& T features. Environmental Science \& Technology 26 (9), 1684-1693.

BAN, (2005). The digital dump: exporting re-use and abuse to Africa. BaselAction Network. Jim Puckett (Editor). $<$ www.ban.org>.

Brigden, K Labunska, I Santillo, D.and Allsopp, M. (2005). Recycling of electronic waste in china and India, issue toxic tech. Brigden, K Labunska, I Santillo, D Allsopp, M Greenpeace Research Laboratories, Department of Biological Sciences, University of Exeter, and Exeter EX4 4PS, UK.

Brett H. Robinson, BH, (2009). E-Waste: An Assessment of Global Production and Environmental Impacts. Science of the Total Environment 408, (2), 183-91.

Carter, C.R. and Ellram, L.M. (1998). Reverse Logistics: A review of the literatur and framework for future investigation, Journal of Business Logistics, 19 (1), 85-102.

Furter, L., (2004). E-waste has dawned. Resource, 8-11. Greenpeace, recycling of electronic waste in China and India. Workplace and environmental contamination. Greenpeace Report

Guptha, C.K.N, and Shekar, G.L. (2009). Electronic Waste Management System in Bangalore - A Review JK Journal of Management \& Technology, ISSN 0975-0924. 1(1), 11-24

Hadi, P., Barford, J. and McKay, G, (2013). Electronic Waste as a New Precursor for Absorbent Production. The SIJ Transactions on Industrial, Financial \& Business Management (IFBM), 1 (4), 126-135.

Jun-Hui, Z, and Hang, M (2009). Eco-Toxicity and Metal Contamination of Paddy Soil in an E-Wastes Recycling Area, J. Hazard. Mater.165, 744-750.

Krikke, H.R.; Harten, A. and Schuur, P.C. (1999). Business case Roteb: recovery strategies for monitors. Computers and Industrial Engineering, 36 (4), 739-757.

Leung, A., CAI, Z.W. and Wong, M.H. (2004). Environmental contamination from e-waste recycling at Guiyu, Southeast China. In: Proceedings of the 3rd Workshop on Material Cycles and Waste Management in Asia, Tokyo, $14(15), 73-84$.

Lincoln, J.D., Ogunseitan, O.A., Shapiro A. A., and Saphores J.D.M. (2007). Assessments ofHazardous Materials in Cellular Telephones. Environmental Science and Technology 41(7), 2572 2578. Available:

http://pubs3.acs.org/acs/journals/doilookup?in_doi=10.1021/es0610479

Luo, C., Liu, C., Wang, Y., Liu, X., Li, F. and Zhang (2011). "Heavy Metal Contamination in Soils and Vegetables near an E-waste Processing Site, South China”, J. Hazard. Mater. 186, 481-490.

Mehra, H.C. (2004). PC waste leaves toxic taste, The Tribune, 22nd March. [Online], available at:http//www.ijmbr.org/pdf?_1782ᄀ_46bce76e3a370791e65fa55ce28ffobd.html [accessed on 20 April 2014].

Musson, S.E., Vann, Y.C. Jang, S., Mutha, A. Jordan, B. and Pearson, K.N. (2006). "RCRA Toxicity Characterization of Discarded Electronic Devices", Environ. Sci. Technol. 40, 2721-2726

Musson, S.E., Jang, Y.-C., Townsend, T.G. and Chung, I.-H., (2000). Characterization of lead

Leachability from cathode ray tubes using the toxicity characterization leaching procedure. Environmental Science \& Technology, 34, 4376-4381.

Noon, M.S, Lee, S.J, and Cooper, J.S. (2011), “A Life Cycle Assessment of End-of-Life Computer Monitor Management in the Seattle Metropolitan Region", Resources, Conservation and Recycling, 57, 22-29. 
Anin. E. K., Djan-Yeboah, J., \& Okyere. S. (2015). Assessing Electronic Waste Disposal Practices as a Function of Reverse Logistics: Evidence from Kumasi Metropolis, Ghana. Archive Research Journal, 3(2), 20-32.

Nnorom, IC, Osibanjo, 0 (2007). Electronic waste (e-waste): Material flows and management Practices in Nigeria. Waste Management 28 1472-1479

Roman, L.S. and Puckett, J. (2002). E-scrap Exportation: Challenges and Considerations. In: Proc. International Symposium on Electronics and the Environment 2002 IEEE. San Francisco CA USA. 79-84.

Sinha, D. (2004). The Management of Electronic Waste: A Comparitive Study on India and Switzerland. A University of St.Gallen Master Thesis in Cooperation with EMPA

Stock, J.R. (1998). Development and Implementation of Reverse Logistics Programs. Council of Logistics Management.

Taye, M. and Kanda, W. (2011), E-waste management in Botswana. Master Degree Thesis, Division of Environmental Technology and Management, Linkoping University, Sweden, 1-74.

Thierry, M., Salomon, M., Nunnen, J. and Wassenhove, L. (1995). Strategic issues in Product Recovery Management. California Management review, winter, 37(2), 114-135.

Tibben-Lembke, R. S.and Rogers, D. S. (2002), Differences between forward and reverse Logistics in a retail environment. Supply Chain Management: An International Journal, 7 (5), 271 - 282.

Ritchie, L., Burnes, B.; Whittle, P. and Hey, R. (2000). The benefits of Reverse Logistics: the case of Manchester Royal Infirmary Pharmacy. Supply Chain Management: an international Journal, 5 (5), 226-233.

Rogers, D.S. and Tibben-Lembke, R.S. (1998), “Going Backwards: Reverse Logistics Trends and Practices”, RLEC Press, Pittsburgh, PA., 283

Rogers, D.S. and Tibben-Lembke, R. S. (2002). Differences between forward and reverse Logistics in a retail environment. Supply Chain Management: An International Journal, 7(5), 271-282.

Rupnow, P. (2006). Increase Profits using the Reverse Logistics Cost Equation, ReverseLogistics Magazine, 30-32.

World Bank (2007). Ghana Country Environmental Analysis, Report No. 36985-GH, 2.11

$\mathrm{Wu}$, (2008). Electronic Waste Management in India-Issues and Strategies [online],

Available at: http//www.ijrmbss.com/assets/pdf/vol. 1 less 1/9a.pdf 